\author{
Joanna Szczęsna \\ https://orcid.org/0000-0003-3824-7247 \\ Monika Wesołowska \\ https://orcid.org/0000-0002-6110-0270 \\ Uniwersytet Marii Curie-Skłodowskiej w Lublinie \\ Wydział Nauk o Ziemi i Gospodarki Przestrzennej \\ Instytut Geografii Społeczno-Ekonomicznej i Gospodarki Przestrzennej \\ joanna.szczesna@poczta.umcs.lublin.pl \\ monika.wesolowska@poczta.umcs.lublin.pl
}

\title{
OCENA WPŁYWU NOWYCH PRODUKTÓW TURYSTYCZNYCH NA OŻYWIENIE GOSPODARCZE OBSZARÓW WIEJSKICH W ŚWIETLE BADAŃ EMPIRYCZNYCH WYBRANYCH GMIN WOJEWÓDZTWA LUBELSKIEGO
}

\begin{abstract}
Abstrakt: W opracowaniu zaprezentowano przykłady kilku oryginalnych produktów turystycznych, dostępnych na obszarach wiejskich województwa lubelskiego, które w świetle przeprowadzonych badań empirycznych przyczyniły się do rozwoju funkcji turystycznej w miejscach swojego występowania. Głównym celem artykułu jest określenie, w jaki sposób zostały wykreowane wybrane produkty turystyczne i jaka jest ich rola w rozwoju funkcji turystycznej i w rozwoju lokalnym w ogóle. W artykule wykorzystano metodę analizy przypadków, która dotyczyła czterech produktów zlokalizowanych w czterech gminach województwa lubelskiego. Oceny wpływu wykreowanego produktu turystycznego na rozwój lokalny dokonano na podstawie badań przeprowadzonych metodą sondażu diagnostycznego w formie kwestionariusza ankiety i wywiadu bezpośredniego. Wywiady na temat procesu tworzenia produktu turystycznego i jego efektów przeprowadzono z przedsiębiorcami z branży turystycznej, natomiast kwestionariusze ankiety dotyczące wpływu powstałego produktu turystycznego na rozwój lokalny skierowano do mieszkańców gmin objętych badaniem. Wyniki pokazały, że w każdym z badanych przypadków wykreowanie produktu turystycznego mogło mieć znaczący wpływ na rozwój funkcji turystycznej oraz rozwój gospodarczy obszarów wiejskich, w których te produkty powstały. Zjawiska społeczno-ekonomiczne towarzyszące rozwojowi funkcji turystycznej są pozytywnie postrzegane przez mieszkańców badanych gmin, którzy w rozwoju turystyki upatrują szansę na poprawę warunków ich życia oraz wizerunku ich miejscowości.
\end{abstract}

Słowa kluczowe: obszary wiejskie w Polsce, produkt turystyczny, województwo lubelskie.

\section{WSTĘP}

Współczesny rozwój obszarów wiejskich zarówno w Polsce, jak i na świecie przebiega w trzech zasadniczych kierunkach: przeformułowania (regrounding) - zmniejszenia wydatków na produkcję i inwestycje rolnicze, poszukiwania nowych źródeł dochodów; pogłębiania (deepening) - produkcji wysokiej jakości żywności, w tym również żywności ekologicznej; oraz poszerzania (broadening) - pojawiania się nowych form działalności, np. turystyki (Halamska, Śpiewak, 2008). Za podstawowy czynnik rozwoju danego obszaru, w tym również pod względem turystyki, uznaje się potencjał wewnętrzny regionu (Kuciński, 1994;
Stanny, 2013). Bezpośredni wpływ na rozwój turystyki mają: występowanie i ranga walorów turystycznych (przyrodniczych i kulturowych), zagospodarowanie turystyczne oraz dostępność komunikacyjna (Lijewski, Mikułowski, Wyrzykowski, 2002; Rogalewski, 1974). Butowski (2010) uzupełnia tę listę czynników endogenicznych o promocję i informację turystyczną, tworzenie i komercjalizację produktu turystycznego, czyli elementy marketingu terytorialnego, a także uwarunkowania społeczno-gospodarcze, kulturowe, polityczne, ekologiczne (postawa miejscowej społeczności w stosunku do turystów, działania władz publicznych). 
Inteligentna wieś (smart village) wykorzystuje swoje mocne strony i zasoby w celu rozwijania nowych możliwości. Według Górki i Łuszczyka (2013) dotyczy to usług tzw. wysokiej szansy, czyli takich, które mają perspektywę na trwały rozwój. Mieszkańcy smart village wdrażają inteligentną specjalizację m.in. w zakresie projektów turystycznych (Portal Inteligentnych Wiosek, 2017). Wprowadzenie funkcji turystycznej wpisuje się w koncepcję odnowy wsi i wielofunkcyjnego użytkowania przestrzeni wiejskiej, może się także przyczynić do wzmocnienia ekonomicznego, wielokierunkowego rozwoju i wzrostu jakości życia mieszkańców wsi, a także być czynnikiem wpływającym na rewitalizację obszarów wiejskich. W literaturze przedmiotu badania funkcji turystycznej obszarów wiejskich w Polsce udowadniają że turystyka może rzutować na aktywizację społeczno-gospodarczą tych terenów (Durydiwka, 2012).

Jednym z warunków rozwoju funkcji turystycznej jest kreowanie interesującego produktu turystycznego. Obszary wiejskie mają duży potencjał tworzenia produktów turystycznych, bazujących na lokalnej przestrzeni, przyrodzie, historii czy kulturze bądź będących efektem obserwacji potrzeb rynku lub wyobraźni odpowiedzialnych za nie osób. W obecnych czasach turysta poszukuje nowych doznań i emocji, nowoczesności, zaskoczenia i zachwytu, tzw. efektu „wow!” (Stasiak, 2013, 2015). Doświadczanie, wiedza, rozrywka i emocje tworzą swoiste zestawienie, nazwane triadą doświadczeń turystycznych, stosowaną w kreowaniu nowoczesnej oferty turystycznej (Stasiak, Włodarczyk, 2013).

W niniejszym artykule zaprezentowano kilka oryginalnych produktów turystycznych zlokalizowanych na obszarach wiejskich województwa lubelskiego, których stworzenie, według opinii przebadanych respondentów, przyczyniło się do rozwoju funkcji turystycznej oraz zaistnienia znaczących, pozytywnych zmian społecznych i ekonomicznych w środowisku lokalnym. Celem niniejszego opracowania jest określenie uwarunkowań powstania poszczególnych, opisanych w tekście produktów turystycznych, ocena ich wpływu na rozwój turystyczny badanych gmin oraz rola tych produktów w rozwoju lokalnym.

Zaplanowane zadania badawcze zrealizowano w maju 2018 r. w czterech gminach województwa lubelskiego, wykorzystując metody sondażu diagnostycznego w formie kwestionariusza ankiety i wywiadu bezpośredniego. Wywiady dotyczące procesu tworzenia produktu turystycznego i jego efektów przeprowadzono z osobami, które wprowadziły dany produkt na rynek - przedsiębiorcami z branży turystycznej i instytucjami, natomiast ankietę na temat wpływu powstałego produktu turystycznego na rozwój lokalny skierowano do mieszkańców gmin.

\section{PRODUKT TURYSTYCZNY W ROZWOJU FUNKCJI TURYSTYCZNEJ NA OBSZARACH WIEJSKICH}

Funkcja turystyczna przejawia się w działalności społeczno-ekonomicznej w danej lokalizacji (wsi, regionie), skierowanej na obsługiwanie turystów, dzięki czemu możliwe jest zaspokajanie określonych potrzeb turystycznych (Kurek, 2008). Współcześnie stanowi ona jedną z podstawowych funkcji pozarolniczych na obszarach wiejskich w Polsce, wspomaga proces ich wielofunkcyjnego rozwoju i jest traktowana jako czynnik wzrostu społeczno-gospodarczego (Durydiwka, 2012; Kowalczyk, 2003; Sikorska-Wolak, 2007). Wśród korzyści wynikających z rozwoju funkcji turystycznej na obszarach wiejskich wymienia się m.in: dywersyfikację źródeł dochodu ludności; wzrost zatrudnienia, a co za tym idzie - większe możliwości dla ludzi młodych; podniesienie poziomu zamożności mieszkańców; rozwój infrastrukturalny i gospodarczy oraz rewitalizację wsi. Ważna rola turystyki w rozwoju wsi znajduje potwierdzenie w licznych programach wsparcia finansowego Unii Europejskiej. W ubiegłych latach w województwie lubelskim projekty z zakresu turystyki były finansowane np. w ramach takich programów, jak: Zintegrowany Program Operacyjny Rozwoju Regionalnego 2004-2006, Regionalny Program Operacyjny Województwa Lubelskiego na lata 2007-2013, Program Operacyjny Rozwój Polski Wschodniej 2007-2013 czy Program Rozwoju Obszarów Wiejskich 2007-2013. Fakt, że turystyka jest istotnym ogniwem rozwoju polskiej wsi, został podkreślony przez wydanie krajowego dokumentu operacyjnego Program rozwoju turystyki na obszarach wiejskich w Polsce (2015), w którym zdefiniowano cele i nakreślono wizję rozwoju turystyki na obszarach wiejskich oraz scharakteryzowano działania, które powinny być wdrażane, aby rozwijać funkcję turystyczną.

Na stopień rozwoju funkcji turystycznej ma wpływ wiele czynników, a za najważniejszy z nich można uznać atrakcyjność turystyczna, czyli cechy przyrodnicze bądź pozaprzyrodnicze obszaru, które decydują o zainteresowaniu turysty (Kurek, Mika, 2008). Zasadniczym elementem wpływającym na atrakcyjność turystyczną obszaru i niezbędnym warunkiem rozwoju funkcji turystycznej jest dostępność produktów turystycznych.

W ujęciu ekonomicznym produktem jest wszystko, co może znaleźć się na rynku, zostać nabyte, użyte, skonsumowane, zaspokajając czyjeś pragnienia czy potrzeby (Kotler, 1994). Produkt to zbiór profitów dla nabywcy, tj. materialnych i niematerialnych cech, charakteryzujących się użytecznością oraz korzyściami funkcjonalnymi, społecznymi, psychologicznymi (Levitt, za: Zdon-Korzeniowska, 2009). Produkt turystyczny 
z kolei to wszystkie dobra i usługi tworzone i kupowane w związku z wyjazdem poza miejsce stałego zamieszkania (Gołembski, 1998). Medlik (1995) wyróżnia produkt turystyczny sensu stricto, czyli wszystko to, co turyści kupuja, oraz produkt turystyczny sensu largo - kompozycja z tego, co turyści robia, oraz z walorów, urządzeń i usług, z których w tym celu korzystają - jest to całość przeżytego doświadczenia od momentu opuszczenia domu do chwili powrotu. W odniesieniu do takiego rozumienia pojęcia produktu turystycznego wieś może oferować zarówno produkt sensu stricto (w postaci obiektów, usług, wydarzeń, wytworów kultury, infrastruktury turystycznej itd.), jak i sensu largo, wzbogacając ofertę rzeczową w specyficzną atmosferę i scenerię wsi, stwarzającą warunki do przeżywania turystyki w szczególny sposób.

Gama produktów turystycznych, które mogą być oferowane na obszarach wiejskich, jest bardzo szeroka. Sznajder i Przezbórska (2004) dzielą te produkty na dziewięć kategorii, takich jak: zakwaterowanie, gastronomia, agroturystyka właściwa, sprzedaż bezpośrednia, wypoczynek, sport, rozrywka, terapia, etnografia. Listę tę można uzupełnić o wiele innych elementów, jak choćby: krajobraz i mikroklimat wiejski, natura, lokalna historia i jej bohaterowie, tradycyjne rzemiosło i produkcja, tradycyjna architektura (mieszkalna, gospodarcza, sakralna), stanowiska archeologiczne, lokalny styl życia itd. Oprócz produktów turystycznych bazujących na autentycznych i tradycyjnych zasobach obszarów wiejskich istnieją także takie, które nie nawiązują do nich w ogóle, a powstanie tych produktów wynika wyłącznie z kreatywności ich twórców (np. parki rozrywki) lub zapotrzebowania rynku (np. kompleksy sportowe).

Zgodnie z oceną Europejskiej Sieci na rzecz Rozwoju Obszarów Wiejskich pomimo potencjału oferowanego przez stały wzrost turystyki w Europie (trzyprocentowy roczny wzrost liczby turystów w ostatnich latach) oferta produktów turystyki wiejskiej jest wciąż stosunkowo ograniczona (European Network for Rural Development, 2019). Dlatego istnieje duże zapotrzebowanie na tworzenie na obszarach wiejskich oryginalnych, interesujących i zróżnicowanych produktów turystycznych zaspokajających różnorodne potrzeby turystów.

\section{CHARAKTERYSTYKA PRODUKTU TURYSTYCZNEGO WYBRANYCH GMIN W WOJEWÓDZTWIE LUBELSKIM}

W niniejszym rozdziale przedstawiono wyniki badań szczegółowych, dotyczących czterech oryginalnych produktów turystycznych zlokalizowanych na obszarach wiejskich województwa lubelskiego. Produkty te to: Magiczne Ogrody w Trzciance (gmina Janowiec, powiat puławski), Nartsport w Rąblowie (gmina Wąwolnica, powiat puławski), Wioska Gotów w Masłomęczu (gmina Hrubieszów, powiat hrubieszowski) oraz Szlak Żelaza i Kowalskich Tradycji w Wojciechowie (gmina Wojciechów, powiat lubelski). W dalszej części artykułu zostaną one pokrótce omówione.

Magiczne Ogrody (fot. 1 i 2 ) jest to rodzinny park tematyczno-sensoryczny, nawiązujący do wątków baśniowych. Koncepcję tego produktu opracował inwestor prywatny. Park działa od 2014 r., został stworzony z myślą o turystach indywidualnych (rodzinny) oraz szkolnych i przedszkolnych grupach zorganizowanych. Po parku oprowadzają animatorzy. Na miejscu znajduje się sklep z pamiątkami (wiele pamiątek spersonalizowanych na potrzeby parku), restauracja oraz kawiarnia. W parku organizowane są imprezy okazjonalne i tematyczne. Dwukrotnie (w 2016 i 2017 r.) internauci w plebiscycie „Top Atrakcje” uznali Magiczne Ogrody za największą atrakcję turystyczną Lubelszczyzny. Park ten otrzymał również w 2015 r. Certyfikat Najlepszego Produktu Turystycznego, przyznany przez Polską Organizację Turystyczną.
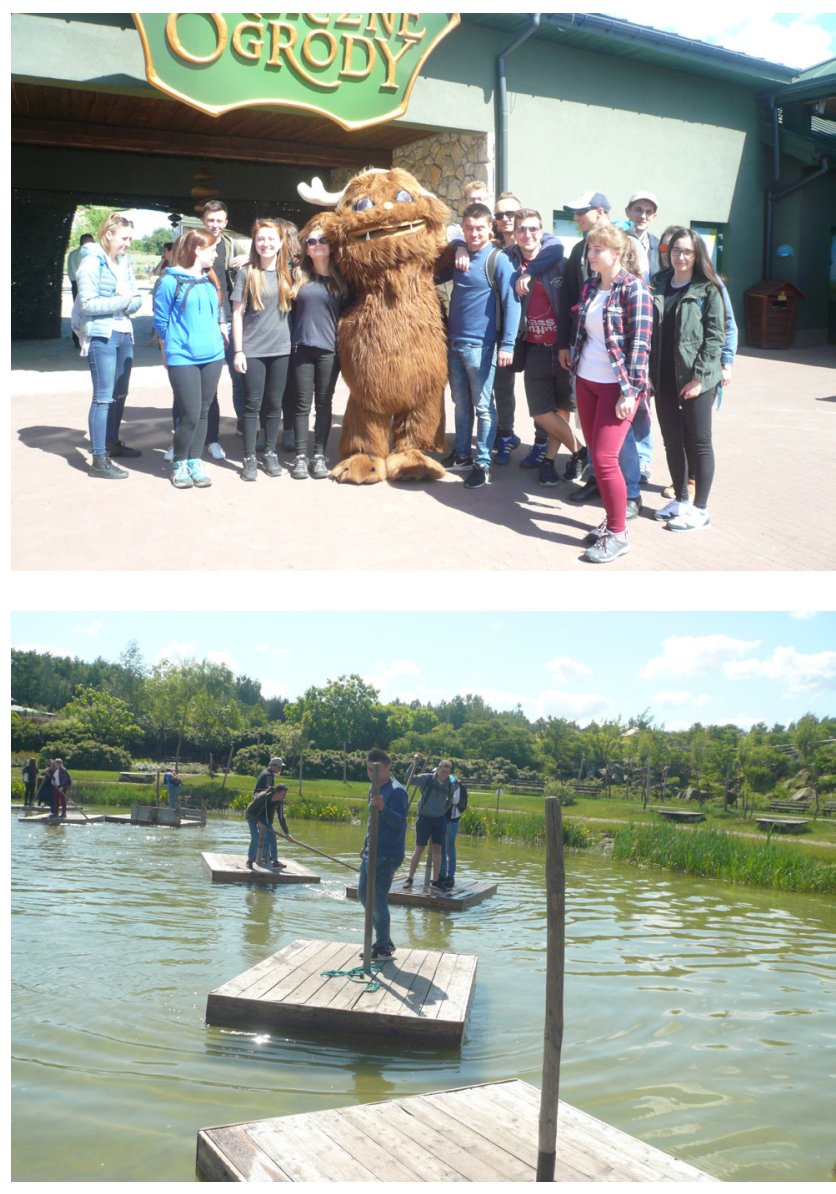

Fotografia 1 i 2. Magiczne Ogrody Źródło: M. Wesołowska 
Nartsport (fot. 3 i 4 ) to kompleks sportowo-rekreacyjny stworzony przez prywatnego inwestora. Powstał w 1993 r. (jako pierwszy na Lubelszczyźnie wyciąg narciarski) ze względu na bardzo duże zapotrzebowanie $\mathrm{w}$ regionie na infrastrukturę do uprawiania sportów zimowych. W następnych latach oferta była stopniowo rozszerzana. Obecnie w sezonie zimowym goście mają tam do dyspozycji stok narciarsko-snowboardowy i saneczkarski oraz wypożyczalnię sprzętu, natomiast w sezonie letnim - baseny, jacuzzi, boisko do siatkówki plażowej, plac zabaw i trampoliny. Ponadto dla turystów dostępne są: restauracja, bar oraz noclegi. W Nartsporcie odbywają się imprezy towarzyszące, integracyjne i okolicznościowe.

Wioska Gotów (fot. 5 i 6 ) to zrekonstruowana wioska historyczno-kulturowa, która powstała w 2008 r. Idea tego produktu bazuje na badaniach archeologicznych, prowadzonych we wsi od 1977 r. Dotyczyły one kultury Gotów - plemienia pochodzenia germańskiego, które dotarło do Kotliny Hrubieszowskiej w II w. n.e.
Po zakończeniu badań, z inicjatywy ludności zamieszkującej wieś, powołano Masłomęckie Stowarzyszenie "Wioska Gotów", którego głównym celem jest popularyzacja wiedzy o kulturowo-historycznym dziedzictwie regionu oraz realizacja przedsięwzięć $\mathrm{w}$ ramach projektu „Gotania”. Obecnie Stowarzyszenie zrzesza 30 osób i prowadzi działalność edukacyjna, naukowa, promocyjną, rozrywkową i gospodarczą. W skansenie można obejrzeć prezentację grupy odtwarzającej życie codzienne Gotów, wziąć udział w warsztatach, "żywych" lekcjach historii i cyklicznych imprezach rekonstrukcyjnych i tematycznych (m.in. Biesiada Archeologiczna), konferencjach naukowych i popularnonaukowych organizowanych przez Stowarzyszenie. Wioska Gotów została uznana w 2017 r. za Najlepszy Produkt Turystyczny Województwa Lubelskiego w kategorii „Obiekt”.

Szlak Żelaza i Kowalskich Tradycji (fot. 7 i 8 ) to zintegrowany produkt publiczno-prywatny, który został stworzony przez gminę i podmioty gospodarcze
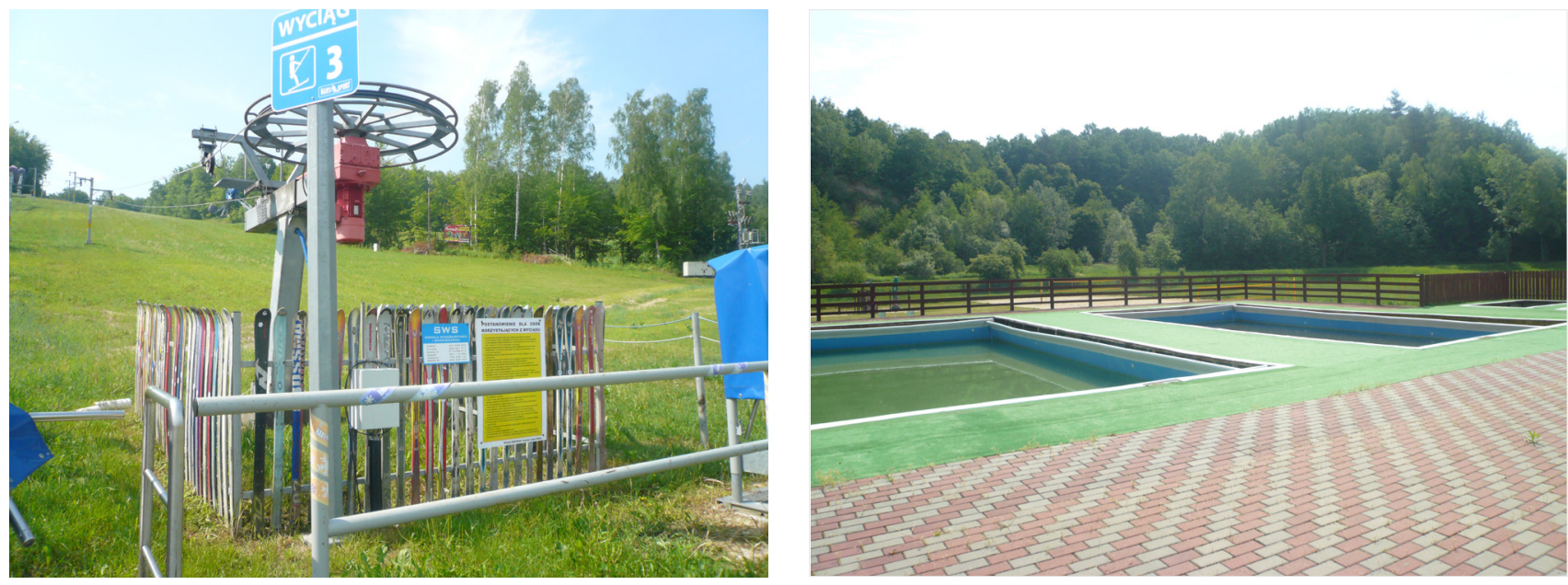

Fotografia 3 i 4 . Kompleks sportowo-rekreacyjny Nartsport Źródło: M. Wesołowska
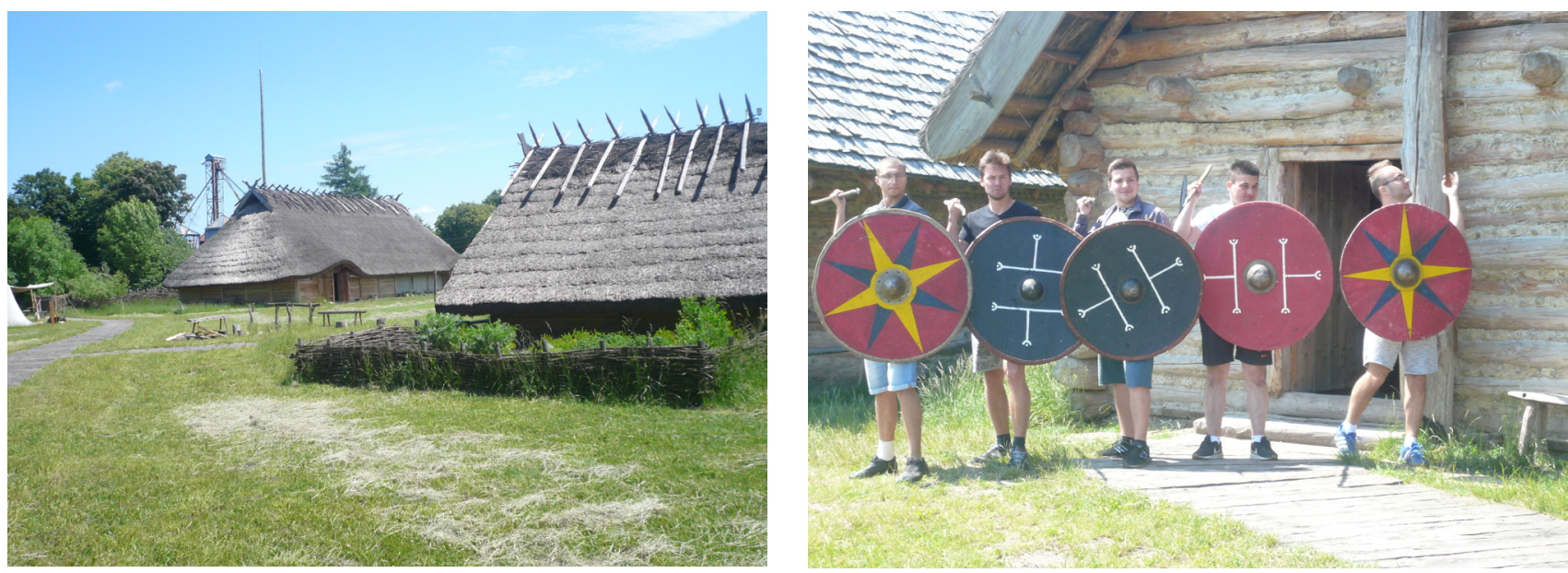

Fotografia 5 i 6 . Wioska Gotów

Źródło: M. Wesołowska 

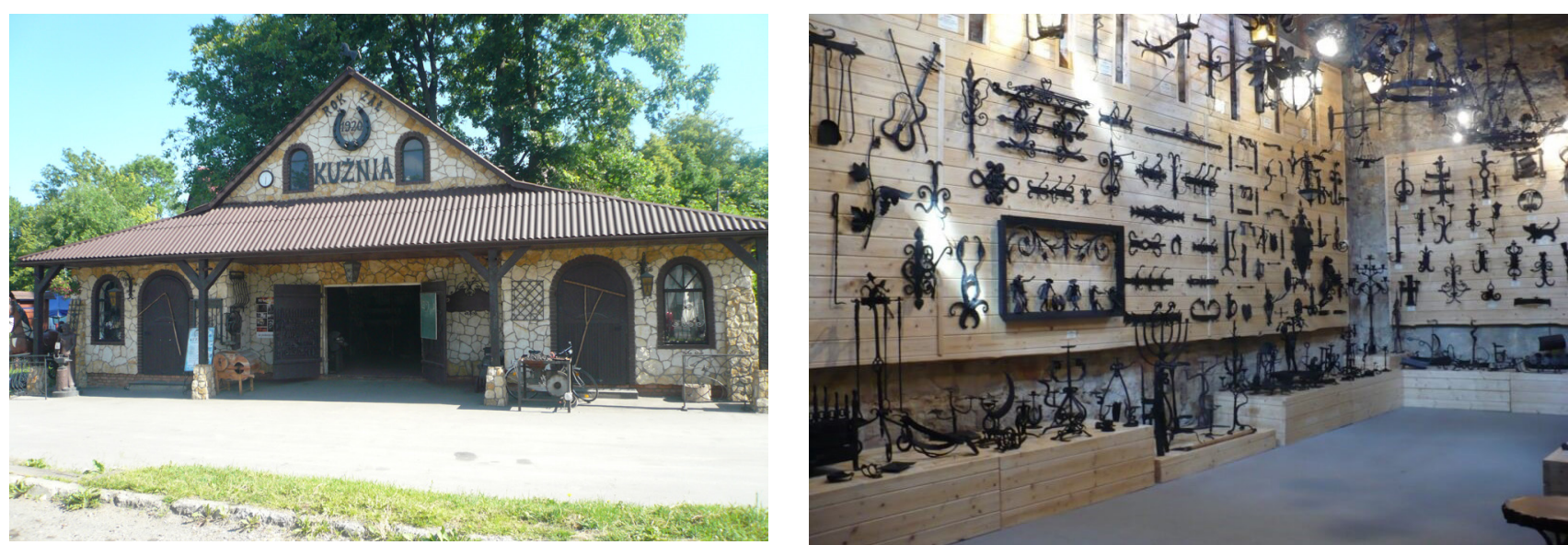

Fotografia 7 i 8. Kuźnia na Szlaku Żelaza i Kowalskich Tradycji

Źródło: M. Wesołowska

w nawiązaniu do lokalnych tradycji kowalskich. Produkt składa się z kilku elementów, takich jak: zwiedzanie Muzeum Kowalstwa i działającej aktualnie kuźni Romana Czernieca, możliwość zjedzenia tradycyjnego posiłku w gospodarstwie agroturystycznym „U Kowalowej" oraz wytapianie i odlewanie metali w dymarce. Dodatkowo turysta może zwiedzić Muzeum Regionalne, uczestniczyć w zajęciach warsztatowych i cyklicznych imprezach kowalskich. W 2009 r. Szlakowi Żelaza i Kowalskich Tradycji nadano tytuł Perełki Lubelszczyzny. W 2010 r. przyznano mu z kolei Certyfikat Polskiej Organizacji Turystycznej za najlepszy produkt turystyczny. W tym samym roku szlak otrzymał również trzecią nagrodę $\mathrm{w}$ konkursie na najciekawszy pakiet turystyki wiejskiej podczas II Międzynarodowych Targów Turystyki Wiejskiej i Agroturystyki AGROTRAVEL w Kielcach.

\section{WYNIKI BADAŃ}

Badanie, którego wyniki przedstawiono w niniejszym artykule, przeprowadzono w maju $2018 \mathrm{r}$. w czterech gminach województwa lubelskiego, z zastosowaniem metody sondażu diagnostycznego (wywiad i ankieta). Celem przeprowadzonych studiów było zebranie opinii na temat wplywu utworzenia produktu turystycznego na rozwój funkcji turystycznej w gminach uwzględnionych w badaniu oraz ocena wpływu funkcjonowania produktu turystycznego na środowisko lokalne. Badanie bezpośrednie (ankieta) wykonano na losowej próbie mieszkańców poszczególnych gmin. Łącznie uzyskano odpowiedzi od 276 osób (gmina Janowiec - 76 ankiet, Hrubieszów - 78, Wąwolnica - 65 i Wojciechów -57). Natomiast w przypadku przedsiębiorców/ instytucji zarządzających wybranym produktem turystycznym badanie przeprowadzono $\mathrm{w}$ formie wywiadu bezpośredniego (cztery wywiady).
Kwestionariusz ankiety skierowanej do mieszkańców składał się z 20 pytań. Na początku respondenci zostali poproszeni o odpowiedź na pytanie: „Czy jest Pani/Pan zadowolona/zadowolony z tego, że w okolicy działa inwestycja?". Większość mieszkańców gmin odpowiedziała, że tak (aż 3/4 respondentów z Janowca i Hrubieszowa, nieco mniej z pozostałych gmin) (tab. 1). Ankietowani uważają że dzięki inwestycji poprawił się wizerunek gminy - powstały nowe drogi i infrastruktura, a mieszkańcy bardziej dbają o swoje posesje. Większość respondentów uważa, że inwestycja w sposób pozytywny oddziałuje na otoczenie (tab. 1), ponieważ daje ona możliwość zatrudnienia lokalnej ludności (głównie w sezonie turystycznym), skutkuje nawiązywaniem współpracy gospodarczej z otoczeniem, wiąże się z podejmowaniem działań na rzecz gminy (imprezy integracyjne, darmowy dostęp do usług dla mieszkańców, sponsoring). Dzięki inwestycji gmina jest rozpoznawalna, a sam produkt przyczynia się do reklamy miejscowości, w której się znajduje. W największym stopniu zauważają to mieszkańcy Wojciechowa (tab. 1).

Respondenci (od $77 \%$ do 83\%) uważają również, że inwestycja przyczyniła się do rozwoju gospodarczego gminy. Potwierdzeniem tego jest fakt, że poza główną inwestycją z myślą o turystach oferowane są inne usługi i rozwija się handel (np. wyrób pamiątek, noclegi, gastronomia, transport, handel produktami lokalnymi), odżywa tradycyjne rzemiosło (garncarstwo, kowalstwo) i powstają nowe, uzupełniające atrakcje turystyczne. Dzięki temu mieszkańcy mają większe zyski, a co za tym idzie - poprawie ulega ich sytuacja bytowa.

Bardzo wielu respondentów (ponad 80\%) uważa, że turystyka przyczynia się do lepszego rozwoju gmin, i chciałoby, aby w większym stopniu rozwijały się one turystycznie - mieszkańcy sami podsuwają różne pomysły i przedstawiają propozycje działań, które wsparłyby ten rozwój. Ankietowani ogólnie dość nisko oceniają aktywność samorządów gminnych w zakresie rozwoju turystyki (tab. 2). Zwracają uwagę na brak 
Tabela 1. Odpowiedzi na pytania dotyczące oddziaływania inwestycji na otoczenie (w procentach)

\begin{tabular}{|c|c|c|c|c|c|c|c|c|c|c|}
\hline \multirow[t]{2}{*}{$\begin{array}{l}\text { Produkt } \\
\text { (gmina) }\end{array}$} & \multicolumn{3}{|c|}{$\begin{array}{c}\text { Czy jest Pani/Pan } \\
\text { zadowolona/zadowolony } \\
\text { z tego, że w okolicy jest } \\
\text { realizowana inwestycja? }\end{array}$} & \multicolumn{2}{|c|}{$\begin{array}{c}\text { Czy dzięki } \\
\text { działalności tego } \\
\text { obiektu/atrakcji } \\
\text { poprawił się } \\
\text { wizerunek okolicy? }\end{array}$} & \multicolumn{3}{|c|}{$\begin{array}{c}\text { Czy uważa Pani/Pan, że inwestycja } \\
\text { oddziałuje na otoczenie? }\end{array}$} & \multicolumn{2}{|c|}{$\begin{array}{l}\text { Czy dzięki } \\
\text { inwestycji } \\
\text { w okolicy } \\
\text { powstały } \\
\text { inne firmy? }\end{array}$} \\
\hline & nie & tak & $\begin{array}{l}\text { jest mi to } \\
\text { obojętne }\end{array}$ & nie & tak & $\begin{array}{c}\text { nie } \\
\text { oddziałuje } \\
\end{array}$ & \begin{tabular}{|c|} 
oddziałuje \\
pozytywnie
\end{tabular} & $\begin{array}{c}\text { oddziałuje } \\
\text { negatywnie }\end{array}$ & nie & tak \\
\hline $\begin{array}{l}\text { Magiczne Ogrody } \\
\text { (Janowiec) }\end{array}$ & 11,7 & 74,0 & 14,3 & 34,2 & 65,8 & 22,1 & 63,6 & 14,3 & 74,7 & 25,3 \\
\hline \begin{tabular}{|l|}
$\begin{array}{l}\text { Wioska Gotów } \\
\text { (Hrubieszów) }\end{array}$ \\
\end{tabular} & 9,0 & 74,3 & 16,7 & 35,9 & 64,1 & 34,6 & 64,1 & 1,3 & 63,6 & 36,4 \\
\hline \begin{tabular}{|l|} 
Nartsport \\
(Wąwolnica)
\end{tabular} & 3,1 & 69,2 & 27,7 & 35,4 & 64,6 & 34,3 & 57,1 & 8,6 & 63,1 & 36,9 \\
\hline $\begin{array}{l}\text { Szlak Żelaza } \\
\text { (Wojciechów) }\end{array}$ & 3,5 & 66,7 & 29,8 & 28,1 & 71,9 & 37,5 & 62,5 & 0,0 & 69,1 & 30,9 \\
\hline Średnia & 6,8 & 71,1 & 22,1 & 33,4 & 66,6 & 32,1 & 61,8 & 6,0 & 67,6 & 32,4 \\
\hline
\end{tabular}

Źródło: badania własne na podstawie ankiety.

Tabela 2. Odpowiedzi na pytania dotyczące rozwoju funkcji turystycznej w gminie (w procentach)

\begin{tabular}{|c|c|c|c|c|c|c|c|c|c|c|c|c|c|c|}
\hline \multirow[t]{2}{*}{$\begin{array}{l}\text { Produkt } \\
\text { (gmina) }\end{array}$} & \multicolumn{2}{|c|}{$\begin{array}{c}\text { Czy chciałaby/ } \\
\text { chciałby Pani/ } \\
\text { Pan, aby } \\
\text { gmina } \\
\text { rozwijała się } \\
\text { w kierunku } \\
\text { turystyki? }\end{array}$} & \multicolumn{2}{|c|}{$\begin{array}{c}\text { Czy chciałaby/ } \\
\text { chciałby Pani/ } \\
\text { Pan, żeby } \\
\text { w okolicy po- } \\
\text { wstały również } \\
\text { inne inwestycje } \\
\text { turystyczne? }\end{array}$} & \multicolumn{2}{|c|}{$\begin{array}{l}\text { Czy gmina } \\
\text { podejmuje } \\
\text { jakieś } \\
\text { działania } \\
\text { na rzecz } \\
\text { rozwoju } \\
\text { turystyki } \\
\text { w okolicy? }\end{array}$} & \multicolumn{2}{|c|}{$\begin{array}{l}\text { Czy gmina } \\
\text { ułatwia } \\
\text { mieszkańcom } \\
\text { dostęp do } \\
\text { funduszy na } \\
\text { rozwój } \\
\text { turystyki? }\end{array}$} & \multicolumn{2}{|c|}{$\begin{array}{l}\text { Czy gmina } \\
\text { zachęca } \\
\text { mieszkańców } \\
\text { do inwesto- } \\
\text { wania } \\
\text { w rozwój } \\
\text { turystyki? }\end{array}$} & \multicolumn{2}{|c|}{$\begin{array}{c}\text { Czy w gminie } \\
\text { są prowadzone } \\
\text { jakieś szkolenia / } \\
\text { działania } \\
\text { edukacyjne do- } \\
\text { tyczące rozwoju } \\
\text { przedsiębiorczo- } \\
\text { ści turystycznej? }\end{array}$} & \multicolumn{2}{|c|}{$\begin{array}{l}\text { Czy uważa } \\
\text { Pani/Pan, że } \\
\text { rozwój } \\
\text { turystyki } \\
\text { przyczyniłby } \\
\text { się do } \\
\text { lepszego } \\
\text { rozwoju } \\
\text { gminy? }\end{array}$} \\
\hline & nie & tak & nie & tak & nie & tak & nie & tak & nie & tak & nie & tak & nie & tak \\
\hline $\begin{array}{l}\text { Magiczne } \\
\text { Ogrody } \\
\text { (Janowiec) }\end{array}$ & 18,4 & 81,6 & 25,0 & 75,0 & 52,0 & 48,0 & 60,8 & 39,2 & 63,3 & 36,7 & 74,7 & 25,3 & 20,0 & 80,0 \\
\hline \begin{tabular}{|l}
$\begin{array}{l}\text { Wioska Gotów } \\
\text { (Hrubieszów) }\end{array}$ \\
\end{tabular} & 24,4 & 75,6 & 25,6 & 74,4 & 44,7 & 55,3 & 42,7 & 57,3 & 48,6 & 51,4 & 58,3 & 41,7 & 9,0 & 91,0 \\
\hline \begin{tabular}{|l|} 
Nartsport \\
(Wąwolnica)
\end{tabular} & 6,2 & 93,8 & 14,3 & 85,7 & 55,7 & 44,3 & 56,7 & 43,3 & 55,7 & 44,3 & 59,3 & 40,7 & 6,1 & 93,9 \\
\hline $\begin{array}{l}\text { Szlak Żelaza } \\
\text { (Wojciechów) }\end{array}$ & 21,1 & 78,9 & 20,7 & 79,3 & 58,2 & 41,8 & 55,4 & 44,6 & 66,1 & 33,9 & 71,2 & 28,8 & 7,1 & 92,9 \\
\hline Średnia & 17,5 & 82,5 & 21,4 & 78,6 & 52,7 & 47,3 & 53,9 & 46,1 & 58,4 & 41,6 & 65,9 & 34,1 & 10,5 & 89,5 \\
\hline
\end{tabular}

Źródło: badania własne na podstawie ankiety.

szkoleń związanych z rozwojem działalności turystycznej oraz zachęty i podpowiedzi dla mieszkańców, a także wsparcia finansowego dla inwestycji. Respondenci wielokrotnie ubolewali nad przeznaczeniem przez gminę niedostatecznych środków finansowych na rozwój turystyki, zwracali również uwagę na to, że powstające inwestycje turystyczne częściej mają charakter prywatny niż samorządowy.

Druga część badań (w postaci wywiadów) została przeprowadzona wśród inwestorów bądź przedstawicieli instytucji zarządzających danym produktem turystycznym. Wyniki pozwoliły na sformułowanie kilku wniosków.
Wszyscy inwestorzy/organizatorzy są zadowoleni z podjęcia działalności związanej z danym produktem turystycznym i uważaja, że jest ona zyskowna. Ponadto znając dzisiejsze realia ekonomiczno-społeczne, ponownie podjęliby się prowadzenia tej inwestycji. Wszyscy respondenci planują także rozwój działalności, który jest jednak uwarunkowany potrzebami finansowymi. Pozyskanie funduszy zewnętrznych, które notabene miały również zasadnicze znaczenie na etapie powstawania poszczególnych przedsięwzięć, wpłynie pozytywnie na rozwój inwestycji. Omówione inwestycje powstały dzięki środkom własnym i udzielanym w ramach dofinansowania z Unii Europejskiej, 
a w przypadku Wioski Gotów całość inwestycji sfinansowano $z$ funduszy zewnętrznych. Wszyscy respondenci potwierdzili, że bez wsparcia finansowego realizacja produktu turystycznego nie byłaby możliwa.

Według oceny inwestorów uruchomienie inwestycji wygenerowało ruch turystyczny na poziomie od kilku do kilkudziesięciu tysięcy gości rocznie, jednak ze względu na tajemnicę przedsiębiorstwa inwestorzy nie zgodzili się na podanie dokładnych informacji na temat liczby odwiedzających. Na podstawie wywiadów i obserwacji bezpośrednich w terenie można jednak stwierdzić, że najwięcej gości kieruje się do Magicznych Ogrodów w gminie Janowiec. Ta inwestycja generuje ruch turystyczny na poziomie kilkudziesięciu tysięcy osób rocznie.

Badani przedsiębiorcy/organizatorzy spotykają się z dobrym odbiorem inwestycji w środowisku lokalnym i zauważają ogólny wzrost zainteresowania mieszkańców rozwojem funkcji turystycznej w gminie. Pozytywne postrzeganie inwestycji jest związane m.in. z szansami zawodowymi, które poszczególne inwestycje stwarzają dla lokalnej ludności, a zwłaszcza dla ludzi młodych. Przedsiębiorcy zatrudniają (choć głównie w sezonie turystycznym) i szkolą pracowników przede wszystkim ze środowiska lokalnego. W Magicznych Ogrodach zatrudnionych jest ponad 100 osób. Co więcej, wszyscy przedsiębiorcy/organizatorzy współpracują ze środowiskiem lokalnym w sferze biznesowej oraz pozabiznesowej - prospołecznie, np. organizując imprezy integracyjne dla mieszkańców, zapewniając nieodpłatny dostęp do atrakcji turystycznych, a nawet sponsorując różne typy działań na rzecz lokalnej społeczności.

Inwestorzy biorący udział w badaniu dostrzegają pozytywny wpływ swojej działalności na rozwój przedsiębiorczości w okolicy. Można stwierdzić, że stanowią oni przykład dla mieszkańców i swoją postawą zachęcają ich do wyzwalania i podejmowania własnej aktywności biznesowej, ale także do dbania o ogólny wizerunek domostw, miejscowości i gmin, w których żyją.

Przedsiębiorcy/organizatorzy, podobnie jak mieszkańcy wspomnianych czterech gmin biorący udział w badaniu, zauważają potrzebę większego zaangażowania samorządów w rozwój funkcji turystycznej - zwłaszcza w zakresie infrastruktury oraz szkoleń i wsparcia dla mieszkańców.

\section{PODSUMOWANIE}

Przeprowadzone badania sondażowe pokazały, że we wszystkich czterech gminach rozwój funkcji turystycznej nastąpił po stworzeniu interesującego produktu turystycznego. $Z$ odpowiedzi ankietowanych wynika, że produkty te miały znaczący wpływ na ożywienie ruchu turystycznego. Na podstawie przeprowadzonego badania, opierając się na opinii mieszkańców i przedsiębiorców, a także na obserwacjach autorek niniejszego artykułu, można wysnuć następujące wnioski:

1. Dzięki rozwojowi turystyki wzrósł poziom gospodarczy gmin i nastąpił rozwój lokalnej przedsiębiorczości, głównie w zakresie handlu i usług, działających na rzecz obsługi turystów.

2. Inwestycje związane z powstaniem poszczególnych produktów turystycznych są pozytywnie postrzegane przez społeczność lokalną. Mieszkańcy gmin widzą potrzebę rozwoju turystyki, upatrując w niej szansę na poprawę sytuacji ekonomicznej. Rozwój turystyki stwarza także możliwości zawodowe młodym ludziom, przyczyniając się $\mathrm{w}$ wielu przypadkach do decyzji o pozostaniu w miejscu zamieszkania, co w sytuacji obserwowanego odpływu młodzieży z obszarów wiejskich ma kolosalne znaczenie dla przyszłości demograficznej wsi. Problemem jest jednak nadal sezonowość branży turystycznej w Polsce i związane z nią czasowe ograniczenia możliwości zarobkowania. Częściowym rozwiązaniem tego problemu może być rozbudowa i dywersyfikacja oferowanych produktów turystycznych z uwzględnieniem zainteresowań i potrzeb różnych grup turystów oraz przygotowanie propozycji na różne pory roku. Przykładem inwestycji z dwusezonową ofertą (na zimę i lato) jest kompleks sportowo-rekreacyjny Nartsport w Rąblowie, a wielosezonowy charakter mają Szlak Żelaza i Kowalskich Tradycji oraz Wioska Gotów.

3. Inwestycje turystyczne mają znaczący wpływ na biznesową i społeczną integrację środowiska lokalnego wsi, które podejmuje współdziałanie na rzecz ogólnego i ekonomicznego rozwoju gminy. Widoczne są także inne pozytywne efekty zrealizowanych projektów. Opisane $w$ artykule inwestycje przyczyniły się do poprawy estetyki gmin, a także do zachowania i rozwijania dziedzictwa kulturowego badanych obszarów. Ponadto wzrosła rozpoznawalność i popularność gmin wśród przyjezdnych, a mieszkańcy w większym stopniu zaczęli odczuwać dumę z miejsca zamieszkania. Nastąpiło również umocnienie ich lokalnej tożsamości.

4. Najsłabszym ogniwem w procesie rozwoju turystycznego w badanych przypadkach są samorządy lokalne. Zarówno mieszkańcy, jak i organizatorzy opisanych produktów turystycznych oceniaja, że wkład samorządów gminnych w inwestycje turystyczne jest zbyt mały. Większość zrealizowanych koncepcji ma charakter prywatny i opiera się na przedsiębiorczości i kreatywności indywidualnych inwestorów lub instytucji stowarzyszeniowych, jedynie Szlak Żelaza i Kowalskich Tradycji jest projektem gminno-prywatnym. Zdaniem ankietowanych konieczne jest także większe zaangażowanie lokalnych instytucji samorządowych w edukację i wsparcie 
doradcze oraz finansowe mieszkańców w zakresie rozwoju funkcji turystycznej,

5. Opisane produkty turystyczne mają charakter lokalny i nie są powiązane w sieć atrakcji położonych w różnych gminach, nie mają także wspólnej infrastruktury turystycznej. Zdecydowanie brakuje produktów zintegrowanych, uzupełniających się, mających charakter międzygminny, które mogłyby przyciagnąć turystów i stać się zachętą do dłuższego pobytu. Jest to kolejny obszar wymagający zaangażowania i działania koordynującego samorządów gmin, a także współpracy pomiędzy poszczególnymi gminami.

Reasumując, na podstawie opisanych przypadków można stwierdzić, że stworzenie interesującego produktu turystycznego jest czynnikiem kształtowania się funkcji turystycznej na terenach wiejskich i przyczynia się do rozwoju społeczno-gospodarczego tych obszarów. Podaż tego typu produktów jest jednak na razie stosunkowo mała, natomiast w celu jej zwiększenia działania o charakterze koncepcyjnym, edukacyjnym i finansowym powinny zostać podjęte nie tylko przez podmioty indywidualne, ale także przez samorządy gminne.

\section{BIBLIOGRAFIA}

Butowski, L. (2010). Turystyka jako czynnik rozwoju w świetle wybranych teorii rozwoju regionalnego. Turyzm/Tourism, 20 (1), 5-11.

Durydiwka, M. (2012). Czynniki rozwoju i zróżnicowanie funkcji turystycznej na obszarach wiejskich w Polsce. Warszawa: Uniwersytet Warszawski, Wydział Geografii i Studiów Regionalnych.

European Network for Rural Development (2019). Pobrane z: https://enrd.ec.europa.eu/ (28.06.2019).

Gołembski, G. (1998). Przedsiębiorstwo turystyczne w gospodarce wolnorynkowej. Poznań: Wydawnictwo Akademii Ekonomicznej.

Górka, K., Łuszczyk, M. (2013). Inteligentna specjalizacja czy raczej sektor „wysokiej szansy” atutem w rozwoju regionów. Studia KPZK PAN, CLV, 52-60.

Halamska, M., Śpiewak, R. (2008). Rozwój wiejski - nowa utopia czy konieczność? W: M. Drygas, A. Rosner (red.), Polska wieś i rolnictwo w Unii Europejskiej. Dylematy i kierunki przemian (s. 393-416). Warszawa: IRWiR PAN.
Kotler, P. (1994). Marketing - analiza, planowanie, wdrażanie i kontrola. Warszawa: Gebethner i S-ka.

Kowalczyk, A. (2003). Tourism as a factor of local development. W: A. Kowalczyk (red.), Geographical space at the turn of the century (s. 217-222). Warszawa: Uniwersytet Warszawski, Wydział Geografii i Studiów Regionalnych.

Kuciński, K. (1994). Geografia ekonomiczna. Zarys teoretyczny. Warszawa: Wydawnictwo SGH.

Kurek, W. (red.) (2008). Turystyka. Warszawa: Wydawnictwo Naukowe PWN.

Kurek, W., Mika, M. (2008). Turystyka jako przedmiot badań. W: W. Kurek (red.), Turystyka (s. 11-48). Warszawa: Wydawnictwo Naukowe PWN.

Lijewski, T., Mikułowski B., Wyrzykowski, J. (2002). Geografia turystyki Polski. Warszawa: PWE.

Medlik, S. (1995). Leksykon podróży, turystyki, hotelarstwa. Warszawa: Państwowe Wydawnictwo Naukowe.

Portal Inteligentnych Wiosek (2017). Pobrane z: https://enrd. ec.europa.eu/smart-and-competitive-rural-areas/smart-villages/smart-villages-portal_pl (20.09.2018).

Program rozwoju turystyki na obszarach wiejskich w Polsce (2015). Pobrane z: http://ksow.pl/fileadmin/user_upload/ksow.pl/ PROJEKTY_2015/Program_rozwoju_turystyki/Program_rozwoju_turystyki_na_obszarach_wiejskich_wersja_ko\%C5\%84c. pdf (30.09.2018).

Rogalewski, O. (1974). Zagospodarowanie turystyczne. Warszawa: Wydawnictwa Szkolne i Pedagogiczne.

Sikorska-Wolak, I. (red.) (2007). Turystyka w rozwoju obszarów wiejskich. Warszawa: Wydawnictwo SGGW.

Stanny, M. (2013). Przestrzenne zróżnicowanie rozwoju obszarów wiejskich $w$ Polsce. Warszawa: IRWiR PAN.

Stasiak, A. (2013). Nowe przestrzenie i formy turystyki w gospodarce doświadczeń. Turyzm/Tourism, 23 (2), 65-74. DOI: https://doi.org/10.2478/tour-2013-0012

Stasiak, A. (2015). Triada doświadczeń turystycznych i efekt „wow!" podstawą kreowania nowoczesnej oferty turystycznej. Prace Naukowe Uniwersytetu Ekonomicznego we Wrocławiu, 379, 332-347. DOI: https://doi.org/10.15611/pn.2015.379.32

Stasiak, A., Włodarczyk, B. (2013). Miejsca spotkań kultury i turystyki. W: B. Krakowiak, A. Stasiak, B. Włodarczyk (red.), Kultura i turystyka - miejsca spotkań (s. 29-46). Łódź: ROTWŁ.

Sznajder, M., Przezbórska, L. (2004). Identification of rural and agri-tourism product and services. Roczniki Akademii Rolniczej w Poznaniu, CCCLIX, 166-177.

Zdon-Korzeniowska M. (2009). Jak kształtować regionalne produkty turystyczne. Teoria i praktyka. Kraków: Wydawnictwo Uniwersytetu Jagiellońskiego.

Artykuł wpłyną: 12 lipca $2019 \mathrm{r}$. Zaakceptowano do druku: 29 kwietnia $2020 \mathrm{r}$. 